\title{
OBSERVATIONS ON POWER TOBOGGANS
}

\section{by FRANK C. SWITZER*}

The winter of 1969 was really the last winter when power toboggans caused little damage in the two provincial parks I am familiar with - Good Spirit and Duck Mountain, Saskatchewan. The following comments are my personal observations and others that I have read or heard about.

The most important factor to me. personally, is the assault on my ears when, after having walked into a remote area specifically to escape from mechanized noise. one of these cursed machines roars into the beautiful silence.

The most noticeable damage done by power toboggans is to trees and shrubs. It seems necessary to drive these machines off the designated trails and engage in a grand slalom through the trees and underbrush. I grant that most of the plants are probably hidden from the operator by the snow and it is. therefore. more difficult to make him aware of the destruction he causes. One machine operator appeared to be trying to see how much his machine could bulldoze: there were large numbers of saplings up to $3 / 4$ inches broken off and bent in the track. In cold weather the bark on trees, especially the White Poplar, becomes very brittle and a slight knock at the right angle will cause large pieces to shatter off like glass. This leaves an unsightly scar but, more important, it provides a site for plant disease and insect pests to gain an easy foothold. Once disease and insects are established, there is a reservoir of infection that could be spread to healthy plants, if conditions are favourable.

Less noticeable but probably more serious is the compaction of the snow by power toboggans. It is well known that, if left undisturbed. snow is a very

* 1301 Shannon Road.

Regina, Saskatchewan. good insulator. In the thin layer nex to the ground, the crystal structure altered in such a way that it is prac tically unnecessary for small rodent to dig through it: instead, all they hav to do is push or "swim" their wa through it. Studies have been carrie out to determine the effects of natura and man-made compaction of snos and by far the worst effects are man made. The vibration of the powe toboggan and its weight pack the snor tightly to the ground, thereb destroying much of its insulatin quality.

In a coniferous forest there is littl in the way of flora and fauna on th forest floor. The acid condition of th soil. the lack of sun and, even mor importantly, "snow shadow" are con tributing factors. Snow shadow i related to the large percentage o falling snow that is kept off the groun by the branches of the trees, thereb leaving a relatively thin cover of snov on the forest floor. There is then mor likelihood that the ground will freez at a temperature little different from that of the air. What little vegetation there is on the floor of a coniferou forest will suffer still further from lac of insulation where snow toboggan are plentiful.

Thus far we have only commente on plants and only briefly mentione animals. The populations of rodents mainly mice, voles and shrews, tha remain active throughout the winte have three basic needs - food freedom to move to find that food ano warmth. When an area is criss-crosser by power toboggans, barriers to th movement of small rodents under th snow are created. To move in searcho food or in a population expansion these small animals must negotiate th power toboggan trails. The compacter snow under these trails appears to bo too difficult to dig through as seer 
rom the many holes in the sides of the rench. It appears that when a small nimal comes against the packed snow arrier, it tries to tunnel up and over he track. I once found the frozen carcass of a vole in the trench; it would ppear that it came out the side wall of 2 -foot trench and fell to the bottom where it wandered around until it roze to death. The vole had not had ufficient time to dig its way out or to climb high enough to find soft snow to dig through. These hard-packed paths are also handy for coyotes and foxes which probably explains why one does not find more frozen rodents.

Some larger mammals suffer as well when power toboggan operators in. trude on their habitat. I have seen where these vehicles have been driven into deer yards and, in one case, it was quite evident that the operator of the vehicle had one thing in mind: to chase a deer to exhaustion. A predator-eaten carcass at the end of the trail seemed to be proof that he was successful. Upon retracing the predator's tracks, it was found that he had entered the deer yard along the power toboggan trail.

It is upsetting to see the unsporting behaviour of power toboggan operators outside park areas where, all to often, one witnesses a machine being driven after a rabbit, fox or coyote. One wonders if this same behaviour does not go on inside the park as well.

Another area where power toboggans may do unexpected damage is on lakes and ponds. There may not be much hazard in this area yet, as the number of power toboggans on lakes is small. Studies in Wisconsin, I believe, have indicated that excessive packing of snow and the scratching of the ice surface by power toboggan tracks reduces the amount of sunlight transmitted through the ice. This, of course, inhibits photosynthesis and could be a factor in the reduction of oxygen causing winter-kill of fish. Since both of the lakes (Good Spirit and Madge) in these parks are relatively shallow, this could become a problem if power toboggans were restricted to the lakes and many vehicles were encouraged.

More and more we seem to be making the provincial parks into "fun and games" centers. This I believe to be completely wrong. These parks should be returned to a more natural state. This means that mechanized travel within a park should be kept to a minimum. Quiet, leisurely travel should be the order. This means nonmotorized travel such as horseback. bicycle, canoe, row boat. foot-trails etc. The only vehicles in a park would be the ones in use by park staff and those at the campgrounds. There is no need for "fun and games" activities inside what little park land this province has. There is a lot of land outside park property for this kind of thing. Parks are preserves. Let's keep them that way. 